\title{
Purification, Crystallization and Some Properties of Lipase from Geotrichum candidum $\operatorname{Link}^{\dagger}$
}

\author{
Yoshio Tsujisaka, Mieko IwaI and Yoshio TominaGa \\ The Osaka Municipal Technical Research Institute, Osaka, Japan
}

Received December 11, 1972

\begin{abstract}
Lipase (EC 3.1.1.3) of Geotrichum candidum Link was purified by means of ammonium sulfate fractionation, DEAE-Sephadex column chromatography, gel-filtration on Sephadex G-100 and Sephadex G-200, and was finally crystallized in concentrated aqueous solution. It was confirmed that the crystallized preparation was homogeneous electrophoretically and ultracentrifugally.

It was estimated with the crystalline enzyme that the sedimentation constant $\left(s_{20}, w\right)$ was 4.0 , the isoelectric point was pH 4.33, and the molecular weight was $53,000 \sim 55,000$. From the result of amino acid analysis, none of sulfur containing amino acid was detected in the enzyme. It was also recognized that the crystalline preparation contained about $7 \%$ of the carbohydrate and very small amount of lipid. It was characterized that the lipase was the most active at $\mathrm{pH} 5.6 \sim 7.0$ on olive oil, at $40^{\circ} \mathrm{C}$ and was stable in the range of $\mathrm{pH} 4.2$ to 9.8 at $30^{\circ} \mathrm{C}$ for $24 \mathrm{hr}$, and was stable below $55^{\circ} \mathrm{C}$ for $15 \mathrm{~min}$.
\end{abstract}

During the course of our study on lipase, a strain of Geotrichum candidum Link was selected as one of potent lipase producer. As previously reported, it was revealed that this microorganism produced lipase inducibly only in the presence of the specific substance such as vegetable oil or fatty acid in a cultivation medium. ${ }^{1}$ Some reports ${ }^{2 \sim 4)}$ have been published on the production and the specificity of $G$. candidum lipase. Although the application of $G$. candidum lipase for the study on glyceride structure also have been described in those papers, the purification of the enzyme preparation employed in the studies has not been carried out. Therefore, its enzymatic properties in detail were still obscure except its substrate specificity.

On the other hand, the existence of a significant difference of the modes of lipase production by these microorganisms named $G$. candidum has been suggested, since $G$. candidum so far studied by other groups has no requirement of lipid for the enzyme production. Therefore, it seems to be significant to purify $G$. candidum Link lipase, to clarify the property of the purified enzyme and to

\footnotetext{
$\uparrow$ Studies on Lipase. Part VIII.
}

compare the properties of both lipases in further studies.

The present paper deals with the purification and the crystallization procedures and some of the enzymatic properties of $G$. candidum Link lipase.

\section{MATERIALS AND METHODS}

Cultivation. A medium used for cultivation of G. candidum Link was composed of $5 \%$ of corn steep liquor, $1 \%$ of soy bean oil and $0.5 \%$ of ammonium nitrate and was adjusted at $\mathrm{pH} 6.0$. Ten liters of the medium was put into 30-liter jar fermentor (Marubishi Laboratory Equipment Co. Ltd.) and was sterilized at $120^{\circ} \mathrm{C}$ for $30 \mathrm{~min}$. Inoculation was made by the addition of $70 \mathrm{ml}$ of the seed culture broth obtained by $24 \mathrm{hr}$ reciprocal shaking in the same medium as above in Sakaguchi flask at $28^{\circ} \mathrm{C}$. The cultivation was carried out by aeration ( 3 liter $/ \mathrm{min}$ ) and agitation $(200 \mathrm{rpm})$ at $28^{\circ} \mathrm{C}$ for $30 \mathrm{hr}$. After the cultivation, the cells were filtered off and the filtrate was subjected to further purification of lipase.

Assay of lipase activity. Lipase activity was assayed as described previously. ${ }^{5}$ The activity which liberated $1 \mu$ mole equivalent of fatty acid from olive oil per minute was defined as 1 unit (U).

Determination of protein. Protein content in an enzyme preparation was estimated by measurement of 
the absorbancy at wave length $280 \mathrm{~m} \mu$ with Hammarsten milk casein (E. Merk) as a standard. Specific activity of enzyme was expressed as units per $\mathrm{mg}$ of protein.

Physical measurements. Ultraviolet absorption spectrum was measured with a Beckman DB spectrophotometer. Homogeneity of purified enzyme preparation was checked by means of electrophoresis and ultracentrifugation. Analytical electrophoresis was carried out by a Hitachi HT-B Tiselius electrophoresis apparatus. Disc electrophoresis was done by the method of Davis ${ }^{6)}$ with an apparatus of M.S. Instrument Co. Analytical centrifugation was conducted by a Hitachi UC A-1 analytical ultracentrifuge. The estimation of isoelectric point of lipase was accomplished by means of isoelectric-focusing method. The carrier Ampholytes were selected to give a $\mathrm{pH}$ gradient from 3 to 6 and the density gradient was provided by the use of sucrose. Sample was applied in a special vertical electrophoresis column of $110 \mathrm{ml}$ capacity (LKB-Productor).

Analysis of carbohydrate. Total sugar content in the crystallized lipase preparation was determined by phenol-sulfuric acid method.7) Sugar composition was analyzed by following procedure. One milligram of the crystallized lipase preparation was hydrolyzed with $1 \mathrm{~N} \mathrm{H}_{2} \mathrm{SO}_{4}$ at $100^{\circ} \mathrm{C}$ for $3 \mathrm{hr}$. The hydrolyzate was neutralized to $\mathrm{pH} 5.3$ with $\mathrm{BaCO}_{5}$. After removal of the precipitate by filtration, the filtrate was concentrated to $0.1 \mathrm{ml}$ under reduced pressure. Sugar components of the hydrolyzate were analyzed by paper chromatography using a solvent system of $n$ butanol: pyridine: water $(6: 4: 3)$ with double ascending development. Localization of reducing sugar on the filter paper was detected by spraying aniline hydrogen phtharate.

Analysis of amino acid. Each $2.57 \mathrm{mg}$ of the crystallized lipase preparation was hydrolyzed with $6 \mathrm{~N} \mathrm{HCl}$ at $110^{\circ} \mathrm{C}$ for 24,48 , or $72 \mathrm{hr}$, respectively. Amino acids in the hydrolyzate were analyzed by a Hitachi amino acid analyzer KLA-5.

Analysis of lipid. One hundred milligrams of the crystallized lipase preparation were dissolved in chloroform methanol mixture $(2: 1, v / v)$ and oscilated by ultrasonic wave apparatus. Resulting solution was evaporated in vacuum and the solid matter was dissolved in ethyl ether and the insoluble residue was removed. The soluble fraction was saponified with alcoholic $0.5 \mathrm{~N} \mathrm{KOH}$ and acidified with $\mathrm{HCl}$ to $\mathrm{pH} 2.0$. After removing alcohol, ethyl ether was added to the solution. Methylation of the ether soluble fraction was then carried out by the addition of diazomethan. ${ }^{8}$ Then methylated material was subjected to gas liquid chromatography (Column: Diethylene glycol succinate $\left.5 \%, 165^{\circ} \mathrm{C}\right)$.
Other reagents and materials. DEAE-Sephadex A-50, Sephadex G-100 and Sephadex G-200 were the products of Pharmacia Co., Ltd. Carrier Ampholites for electrofocusing were the products of the LKBProductor. All the other materials used were special grade reagents purchased from Wako Pure Chemicals Ltd.

\section{RESULTS AND DISCUSSION}

\section{Purification procedures of lipase}

Ammonium sulfate fractionation. Solid ammonium sulfate was added to 23.3 liters of the culture filtrate of $G$. candidum Link up to the concentration of 0.35 saturation and the precipitate formed was filtered off. To the filtrate, solid ammonium sulfate was further added to give 0.75 saturation. The resulting precipitate was collected by filtration and dissolved in a minimum amount of deionized water. The solution was applied to a column of Sephadex G-25 (coarse) to remove the ammonium sulfate.

DEAE-Sephadex column chromatography. To the desalted solution, a given amount of $1 \mathrm{M}$ acetate buffer, $\mathrm{pH} 5.0$, was added up to $0.01 \mathrm{M}$ in final concentration. The solution was then dialyzed against $0.01 \mathrm{M}$ acetate buffer, pH 5.0, for 2 days. After removal of the precipitate, the filtrate $(2780 \mathrm{ml})$ was applied to a column of DEAE-Sephadex A-50 $(6.2 \times 60 \mathrm{~cm})$ which was equilibrated with the $0.01 \mathrm{M}$ acetate buffer, $\mathrm{pH}$ 5.0. The column was washed thoroughly with the same buffer, and protein adsorbed was eluted by a linear gradient concentration of $\mathrm{NaCl}$ at a flow rate of $42 \mathrm{ml}$ per hr. The effluent was fractionated into $12 \mathrm{ml}$ portions. The main fractions (tube No. 200-220) were combined and concentrated to $50 \mathrm{ml}$ by dialysis against polyethylene glycol (Fig. 1).

Gel filtration on Sephadex G-100. The concentrated solution was chromatographed on a column of Sephadex G-100 $(3.8 \times 120 \mathrm{~cm})$ conditioning with $0.01 \mathrm{M}$ acetate buffer $(\mathrm{pH}$ 5.0). Elution was made with the same buffer at a flow rate of $15 \mathrm{ml}$ per hr and the effluent was fractionated into $12 \mathrm{ml}$ portions. A 


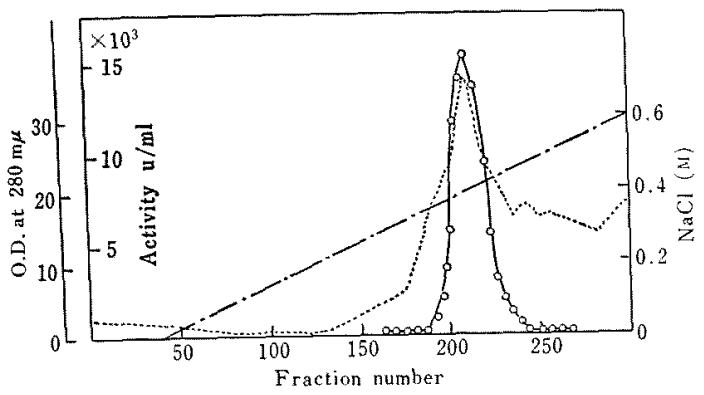

FIG. 1. Column Chromatography of G. candidum Lipase on DEAE-Sephadex A-50.

The experimental details are described in the text.

$\mathrm{O}-\mathrm{O}$ Lipase activity

-...- Protein (O.D. at $280 \mathrm{~m} \mu$ )

-...- $\mathrm{NaCl}$

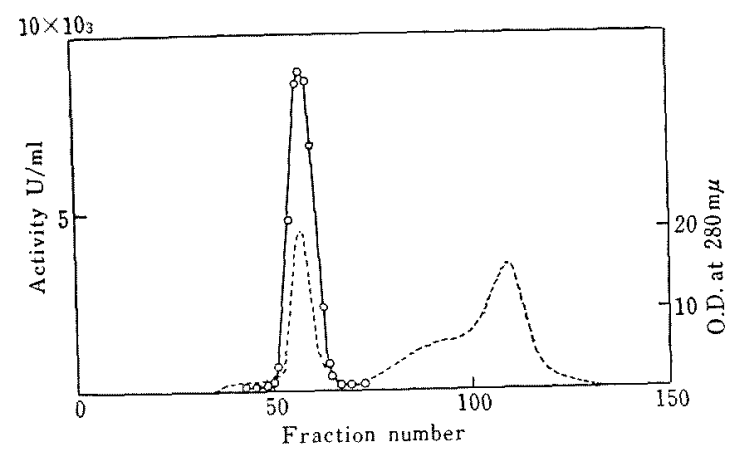

FIG. 2. Column Chromatography of G. candidum Lipase on Sephadex G-100.

The experimental details are described in the text.

$0-0$ Lipase activity

-..... Protein (O.D. at $280 \mathrm{~m} \mu$ )

typical chromatographic pattern obtained in gel filtration was presented in Fig. 2. The active fractions (No. 53 to 62) were combined and dialyzed against deionized water for 2 days and lyophilized. About $1.5 \mathrm{~g}$ of lyophilized powder was obtained.

Gel filtration on Sephadex G-200. The lyophilized powder $(1.5 \mathrm{~g})$ was dissolved in $60 \mathrm{ml}$ of $0.01 \mathrm{M}$ acetate buffer, $\mathrm{pH} 5.0$. Twenty $\mathrm{ml}$ each of the enzyme solution was loaded three times (total, $60 \mathrm{ml}$ ) on a column of Sephadex G-200 $(2.8 \times 104 \mathrm{~cm})$ equilibrated with $0.01 \mathrm{M}$ acetate buffer, $\mathrm{pH} 5.0$. Elution was carried out with the same buffer at a flow rate of $15.2 \mathrm{ml}$ per hr. Effluent was frac- tionated into $6.4 \mathrm{ml}$ portions. As shown in Fig. 3, a symmetric peak of protein with a constant specific activity of lipase was obtained. The fractions having more than 1000 units per $\mathrm{ml}$ were combined and dialyzed against deionized water for 3 days.

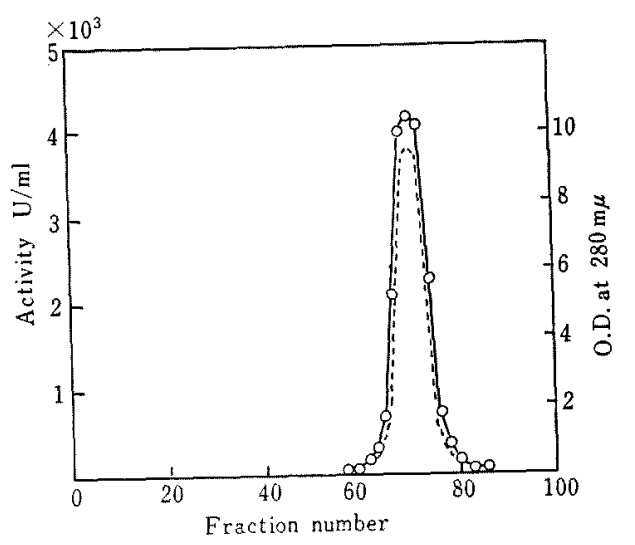

FiG. 3. Column Chromatography of G. candidum Lipase on Sephadex G-200.

The experimental details are described in the text.

O-O Lipase activity

-.. Protein (O.D at $280 \mathrm{~m} \mu$ )

Crystallization. The dialyzed solution was concentrated in a collodion bag under reduced pressure. The crystals slightly appeared when the concentration of protein solution reached to about $10 \%$. After standing the concentrated solution in a cold room $\left(8^{\circ} \mathrm{C}\right)$ for 3 days under reduced pressure, the crystallization was almost completed. The enzyme crystallized from an aqueous solution was separated from mother liquor by centrifugation. The crystals were washed several times with cold deionized water and resuspended in a small amount of cold deionized water. Then, $0.01 \mathrm{~N} \mathrm{NaOH}$ was gently added to the crystal suspension in an ice bath. When $\mathrm{pH}$ of the solution reached to 8.8 , the crystals dissolved completely. After adjusting $\mathrm{pH}$ of the solution to 6.0 with diluted acetic acid, insoluble matter was removed by centrifugation. The supernatant was dialyzed against deionized water. Recrystallization was carried out in the same procedure as the first 


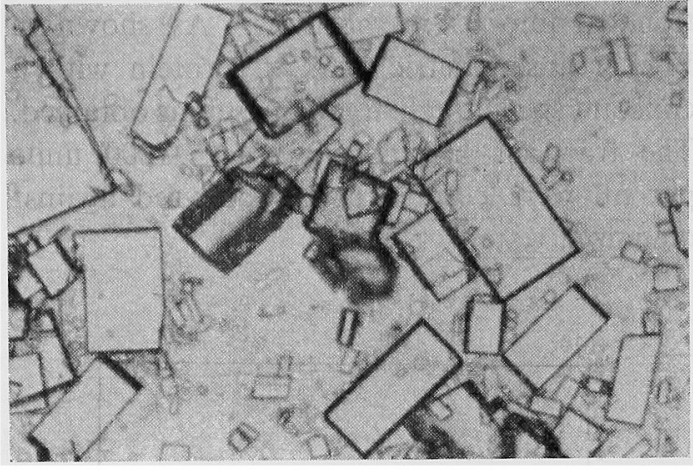

FIG. 4. Crystals of Lipase from Geotrichum candidum Link.

crystallization. The microphotograph of crystals of lipase is shown in Fig. 4. The crystals formed were washed three times with cold deionized water and lyophilized.

The overall procedures of the purification and results are summarized in Tables $I$ and II. The purification results in a 40 fold increase in specific acitivity with a recovery of $20 \%$ of the original activity.

\section{Physical properties of the crystalline lipase}

The homogeneity of the crystallized preparation of lipase from $G$. candidum Link was examined by analytical electrophoresis, disc electrophoresis on polyacryl amide gels and sedimentation. From the results shown in Figs. 5, 6 and 7, it is revealed that the preparation is homogeneous.

The sedimentation constant, $s_{20, \mathrm{w}}$ was determined to be 4.0 , when the experiment
Table I. Purification Procedure of the LIPASE FROM Geotrichum candidum LINK

Culture filtrate

fractionated with ammonium sulfate $(0.25 \sim 0.75$ saturation)

Precipitate

dissolved in deionized water and desalted with a column of Sephadex $\mathrm{G}-25$

Desalted solution

chromatographed on DEAE-Sephadex column equilibrated with $0.01 \mathrm{M}$ acetate buffer, $\mathrm{pH} 5.0$, and eluted by $\mathrm{NaCl}$

Eluted solution

chromatographed on Sephadex G-100 column equilibrated with $0.01 \mathrm{M}$ acetate buffer, $\mathrm{pH} 5.0$, and lyophilized

Lyophylized powder

dissolved in $0.01 \mathrm{M}$ acetate buffer, $\mathrm{pH} 5.0$, and chromatographed on Sephadex G-200 column equilibrated with $0.01 \mathrm{M}$ acetate buffer, pH 5.0.

Eluted solution

dialyzed against deionized water and concentrated by means of a collodion bag under reduced pressure

First crystals

recrystallized

Second crystals

was made from $0.856 \%$ to $0.428 \%$ in protein concentration. Figure 8 shows a plot of sedimentation constants in various protein concentrations.

The molecular weight of the lipase was estimated to be $53000-55000$ by the method of gel filtration using Sephadex G-200 column $(1.6 \times 93 \mathrm{~cm})$. Chymotrypsinogen A (M.W. 25000), ovalbumin (M.W. 45000), bovine

Table II. Lipase Activities in the Course of Purification

\begin{tabular}{lcccc}
\hline \multicolumn{1}{c}{ Fraction and step } & $\begin{array}{c}\text { Total } \\
\text { volume } \\
(\mathrm{ml})\end{array}$ & $\begin{array}{c}\text { Total } \\
\text { activity } \\
(\mathrm{U})\end{array}$ & $\begin{array}{c}\text { Specific } \\
\text { activity } \\
\text { (U/mg protein) }\end{array}$ & $\begin{array}{c}\text { Recovery } \\
\text { of activity } \\
(\%)\end{array}$ \\
\hline Culture filtrate & 23300 & $1.53 \times 10^{6}$ & 11 & 100 \\
Solution of precipitate & 1060 & $1.29 \times 10^{6}$ & 37 & 84 \\
Desalted solution & 2780 & $1.16 \times 10^{6}$ & 50 & 76 \\
DEAE-Sephadex Chromatography & 252 & $1.00 \times 10^{6}$ & 259 & 65 \\
Sephadex G-100 Chromatography & 120 & $7.42 \times 10^{5}$ & 385 & 49 \\
Solution of lyophilized powder & 60 & $5.73 \times 10^{5}$ & 377 & 37 \\
Sephadex G-200 Chromatography & 258 & $4.57 \times 10^{5}$ & 447 & 30 \\
Solution of first crystals & 100 & $3.83 \times 10^{5}$ & 447 & 25 \\
Recrystals & - & $3.07 \times 10^{5}$ & 447 & 20 \\
\hline
\end{tabular}



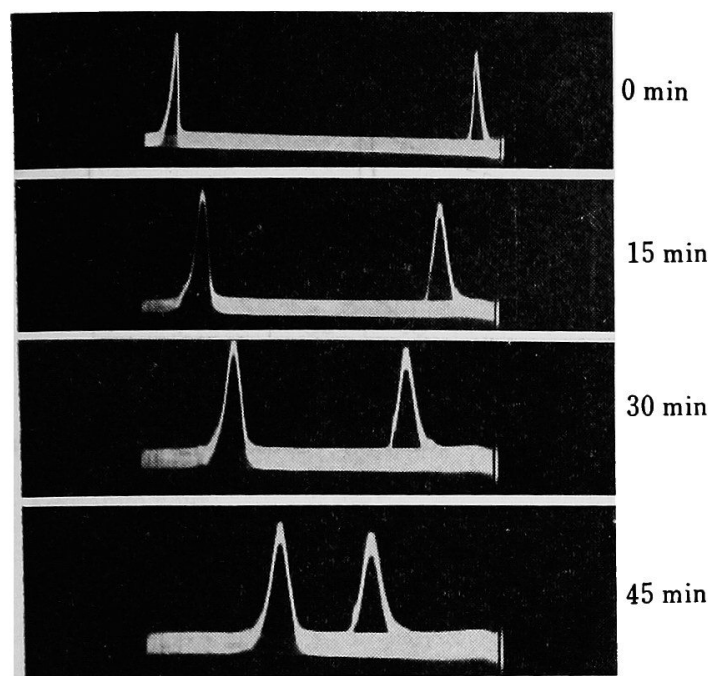

$45 \mathrm{~min}$

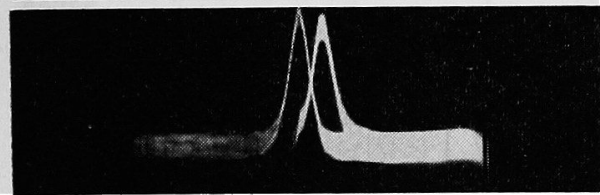

$60 \mathrm{~min}$

FIG. 5. Electrophoretic Patterns of Lipase from G. candidum Link.

The experiment was carried out at a concentration of $1 \%$ lipase in 0.1 ionic strength phosphate buffer at $\mathrm{pH} 7.9$ under the condition of temperature $15^{\circ} \mathrm{C}$, Voltage 100 volt, Ampere $15 \mathrm{~mA}$. The photographs were taken at $0,15,30,45$ and $60 \mathrm{~min}$.

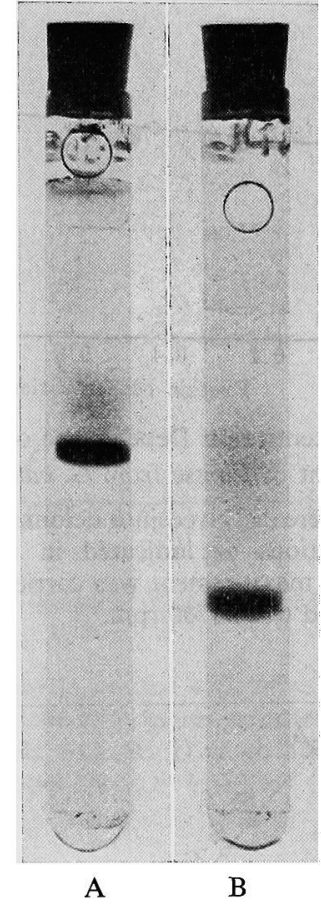

FIG. 6. Disc Electrophoretic Pattern of Lipase from G. candidum Link.

The enzyme, $200 \mu \mathrm{g}$ was applied to the stacking gel and was subjected to electrophoresis in $0.1 \mathrm{M}$ glycine$\mathrm{NaOH}$ buffer, pH 9.4, at a current of $5 \mathrm{~mA}$ for 35 $\min (\mathrm{A})$ and $70 \mathrm{~min}(\mathrm{~B})$.

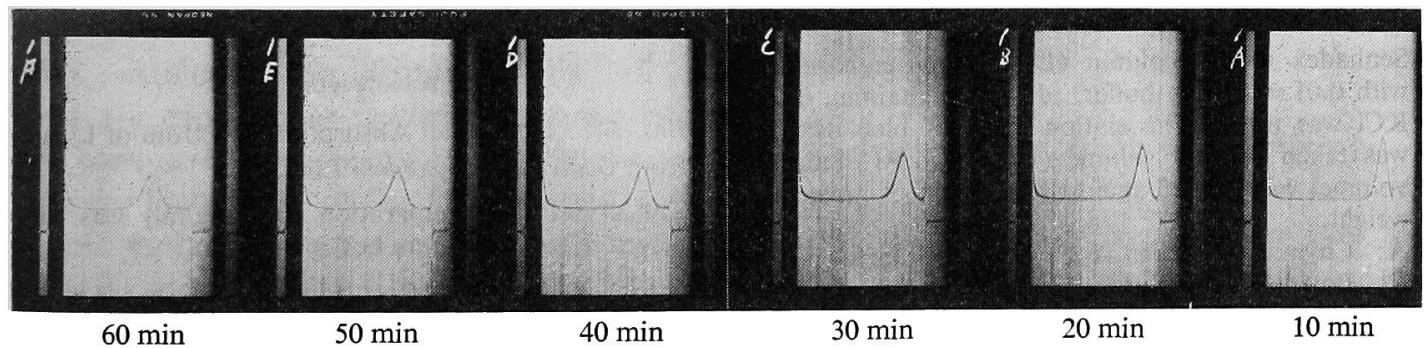

FIG. 7. Sedimentation Patterns of Recrystallized Lipase.

The experiment was carried out at a concentration of $0.856 \%$ lipase in deionized water at $21^{\circ} \mathrm{C}$. The photographs were taken every $10 \mathrm{~min}$ after reaching the final speed $(55700 \mathrm{rpm})$.

serum albumin (M.W. 67000) and $\gamma$-globulin (M.W. 160000) were used as standard proteins for molecular weight determination (Fig. 9). From the result of amino acid analysis as described later, it is considered that the value of M.W. 53000 is reasonable.

The isoelectric point of the lipase was deter- mined by isoelectric-focusing method. It was estimated to be $\mathrm{pH} 4.33$ from the effluent pattern shown in Fig. 10.

The ultraviolet absorption spectrum is shown in Fig. 11, from which $E_{280 \mathrm{~m}, 1 \mathrm{~cm}}^{1 \%}$ was calculated to be 10.8 . 


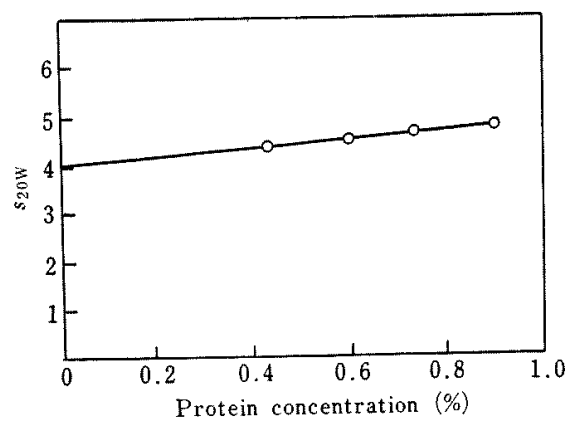

Fig. 8. Concentration Dependence of the Sedimentation Constant of Lipase from $G$. candidum Link.

The crystals were dissolved into deionized water up to the concentrations as indicated in the text. The sedimentation measurement was carried out at $21^{\circ} \mathrm{C}$. The roter speed was $55700 \mathrm{rpm}$.

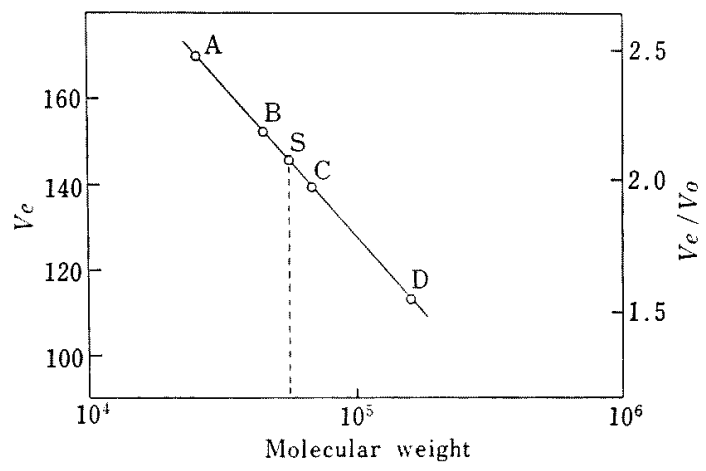

FIG. 9. Estimation of Molecular Weight of the Lipase by Gel Filtration.

Sephadex G-200 column $(1.6 \times 93 \mathrm{~cm})$ equilibrated with $0.01 \mathrm{M}$ acetate buffer, $\mathrm{pH} 5.0$, containing $0.1 \mathrm{M}$ $\mathrm{KCl}$ was used. The elution point of blue dextran was taken as void volume $\left(V_{o}\right)$ and $V_{\varepsilon} / V_{o}$ (elution volume) was plotted against logalithum of molecular weight.
A: Chymotrypsinogen A,
B: Ovalbumin
C: Bovine serum albumin
D: $\gamma$-globulin
S: Lipase

3. Chemical composition of the crystalline lipase

Carbohydrate content of the crystalline lipase preparation was estimated to be $7.5 \%$ as mannose. In the hydrolyzate of the preparation, xylose, arabinose, galactose and mannose were detected by paper chromatography. The paperchromatogram suggested that mannose is the main component among the sugars detected.

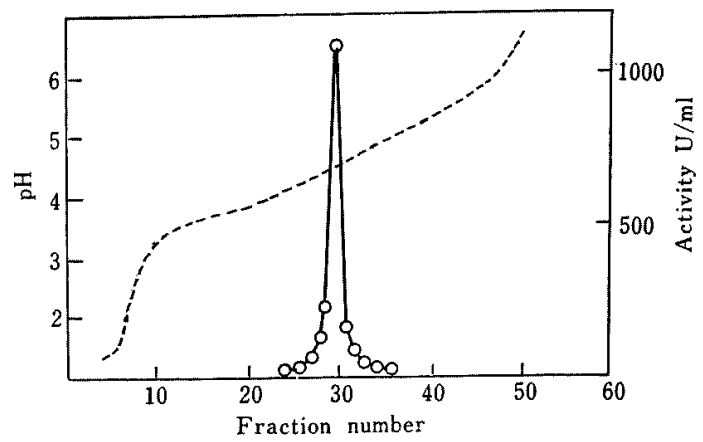

FIG. 10. Electro-focusing Pattern of $G$, candidum Lipase.

The experimental details are described in the text.

$\mathrm{O}-\mathrm{O}$ Lipase activity

-...- $\mathrm{pH}$

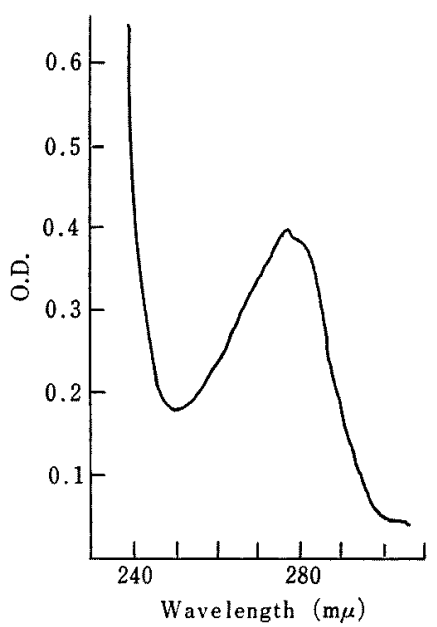

FIG. 11. Ultraviolet Absorption Spectrum of Lipase from Geotrichum candidum Link.

The crystallized preparation $(0.56 \mathrm{mg} / \mathrm{ml})$ was dissolved in $0.01 \mathrm{~m}$ acetate buffer $(\mathrm{pH} \mathrm{5.0)}$.

Table III is summarized the results of amino acid analysis of the crystallized lipase preparation. Sulfur-containing amino acids, such as cystein and methionine were not detected in the hydrolyzate. The lipase is characterized as an enzyme without sulfur-containing amino acid. Accordingly, it seems that the lipase has no $\mathrm{S}-\mathrm{S}$ bond in the molecule structure.

By extraction with chloroform methanol mixture, about $1.1 \mathrm{mg}$ of oily substance was obtained from $101 \mathrm{mg}$ of the crystallized lipase preparation. According to the gas chromato- 
Table III. Amino Acid Composition of the LIPASE FROM Geotrichum candidum LINK

\begin{tabular}{|c|c|c|}
\hline Amino acid & $\begin{array}{c}\text { Amino acid } \\
\text { determined after } \\
\text { hydrolysis for } 24 \mathrm{hr}\end{array}$ & $\begin{array}{l}\text { Numbers of }{ }^{b} \text { ) } \\
\text { residue per } \\
\text { mole of the } \\
\text { enzyme }\end{array}$ \\
\hline Tryptophan ${ }^{\mathrm{e}}$ & 0.0389 & 8 \\
\hline Lysine & 0.0825 & 16 \\
\hline Histidine & 0.0530 & 10 \\
\hline Ammonia & 0.2440 & 46 \\
\hline Arginine & 0.080 & 20 \\
\hline Aspartic acid & 0.283 & 54 \\
\hline Threonine & 0.113 & 22 \\
\hline Serine & 0.147 & 28 \\
\hline Glutamic acid & 0.160 & 30 \\
\hline Proline & 0.141 & 26 \\
\hline Glycine & 0.212 & 40 \\
\hline Alanine & 0.177 & 34 \\
\hline Half-cystine & 0 & 0 \\
\hline Valine & 0.130 & 24 \\
\hline Methionine & 0 & 0 \\
\hline Isoleucine & 0.093 & 18 \\
\hline Leucine & 0.215 & 40 \\
\hline Tyrosine & 0.0963 & 18 \\
\hline Phenylalanine & 0.143 & 28 \\
\hline
\end{tabular}

a) Expressed as micro mol of amino acid residue in 321 micro gram of the enzyme.

b) Calculated on the basis of the value obtained by substracting the carbohydrate content $(7 \%)$ from molecular weight, 53,000.

c) By the method of Goodwin and Movton..$^{3 !}$

graphic pattern, it appears that the oily substance is composed of several kinds of fatty acids. Although, the identifications of all of them are expected to further study, palmitic and oleic acids have been identified so far.

In the literature, ${ }^{10)}$ it has been reported that partial purified preparation of ricinus lipase contains a small amount of lipid which plays an essential role on the enzyme action. In the case of the lipase from $G$. candidum Link, however, it is not still clear whether the lipid is necessary for the enzyme activity. The fact that a small amount of lipid exists in the crystalline lipase might only suggest that the enzyme is happened to be contaminated.

\section{Enzyme property}

Figures 12 and 13 show the effect of $\mathrm{pH}$ on the activity and on the stablity of G. candidum lipase, respectively. The enzyme was the most

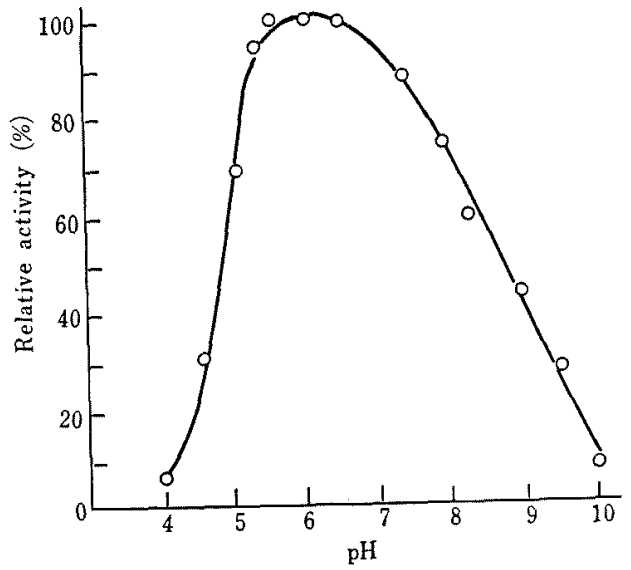

FIG, 12. pH Activity Curve of Lipase from $G$. candidum Link.

The enzyme was incubated with olive oil at $30^{\circ} \mathrm{C}$ for $60 \mathrm{~min}$ at various $\mathrm{pH}$ values adjusted by McIlvain buffer (from $\mathrm{pH} 4$ to $\mathrm{pH} 7$ ) or glycine- $\mathrm{NaOH}$ buffer (from $\mathrm{pH} 6$ to $\mathrm{pH} 10$ ).

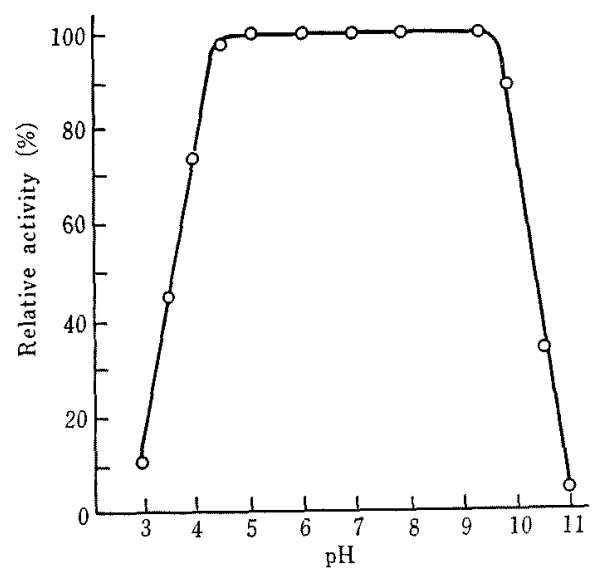

FIG. 13. pH Stability Curve of Lipase from $G$. candidum Link.

Lipase was dissolved in a buffer solution having a $\mathrm{pH}$-value indicated in the figure and incubated at $30^{\circ} \mathrm{C}$ for $24 \mathrm{hr}$. The buffer solution used was $0.05 \mathrm{M}$ McIlvain buffer (from pH 4 to $\mathrm{pH} 8$ ) or Sorensen's glycine- $\mathrm{NaOH}$ buffer (from $\mathrm{pH} 7$ to $\mathrm{pH} 11$ ). Each solution was then diluted with $0.1 \mathrm{~m}$ acetate buffer, $\mathrm{pH}$ 5.6. The remaining activity was determined by the standard assay method.

active at $\mathrm{pH}$ values between 5.6 and 7.0 , and was stable in the range of $\mathrm{pH} 4.6$ to 9.8 during $24 \mathrm{hr}$ incubation at $30^{\circ} \mathrm{C}$.

The effect of temperature on the enzyme activity was examined in the range of $20^{\circ} \mathrm{C}$ to 


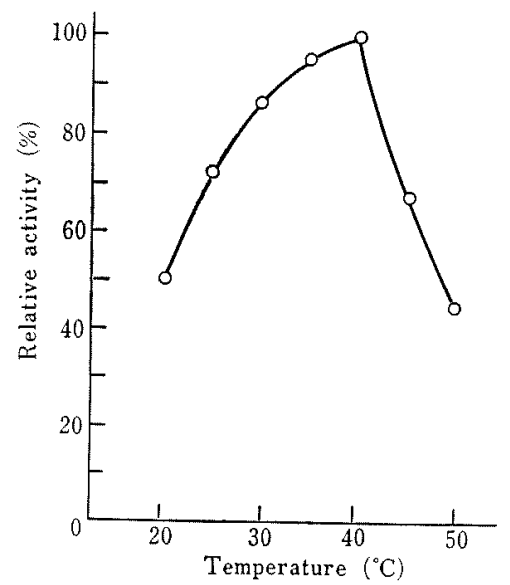

FIG. 14. Effect of Temperature on Activity.

Enzyme reaction was carried out by the standard assay method for $60 \mathrm{~min}$ except temperature was varied.

$50^{\circ} \mathrm{C}$. The optimal temperature was estimated to be at about $40^{\circ} \mathrm{C}$ as shown in Fig. 14.

As shown in Fig. 15, the enzyme was stable at the temperatures below $55^{\circ} \mathrm{C}$ at $\mathrm{pH} 5.6$ for $15 \mathrm{~min}$.

Acknowledgments. The authors are grateful to Dr. J. Fukumoto, Emeritus Professor of Osaka City University, for his encouragement. Thanks are given to Mr. Y. Okamoto and Mr. K. Kanazaki for their assistance with the experiment.

\section{REFERENCES}

1) M. Iwai, Y. Tsujisaka, Y. Okamoto and J. Fukumoto, Agr. Biol. Chem., 37, 929 (1973).

2) W. O. Nelson, J. Dairy Sci., 35, 455 (1952).

3) G. A. Alford and J. L. Smith, J. Am. Oil Chemists Soc., 42, 1029, 1038 (1965).

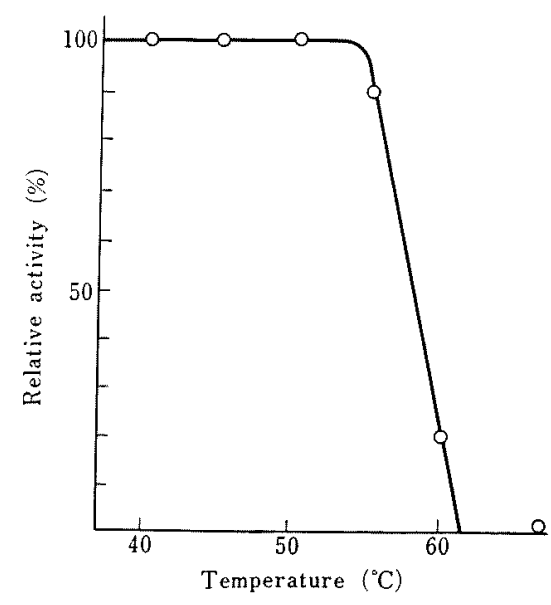

FIG. 15. Effect of Temperature on the Stability.

Each enzyme solution, dissolved in $0.02 \mathrm{M}$ acetate buffer, $\mathrm{pH} 5.6$, was incubated in a test tube at each temperature for $15 \mathrm{~min}$. Then the test tube was kept at $0^{\circ} \mathrm{C}$ for $30 \mathrm{~min}$ and remaining activity was determined by the standard assay method.

4) J. Sampugna and R. G. Jensen, Lipids, 3, 519 (1968).

5) J. Fukumoto, M. Iwai and Y. Tsujisaka, J. Gen. Appl. Microbiol., 10, 257 (1964).

6) B. J. Davis, Ann. New York Acad. Sci., 121, Abst. 2,404 (1964).

7) J. E. Hodge and B. T. Hofreiter, "Method in Carbohydrate Chemistry," Vol. I, ed. by R. L. Whistler and M. L. Wolfrom, Academic Press 1962 , p. 388.

8) H. Schlenk and J.L. Gellerman, Anal. Chem., 32, 1412 (1960).

9) T. W. Goodwin and R. A. Movton, Biochem. $J ., 40,628$ (1946).

10) R. L. Ory, R. H. Barker, and G. J. Boudreaux, Biochemistry, 3, 2013 (1964). 